\title{
Virological response to treatment with peginterferon alfa-2a in adolescents with chronic hepatitis B
}

\author{
Małgorzata Pawlowska ${ }^{\bowtie}$, Waldemar Halota, Dorota Kozielewicz and Ewa Jendryczka \\ Department of Infectious Diseases and Hepatology, Collegium Medicum, Nicolaus Copernicus University, Bydgoszcz, Poland
}

Background: There are few data on the efficacy and safety of pegylated interferon treatment in adolescents with chronic hepatitis B. Aim: We conducted a pilot study in 13 adolescents with chronic hepatitis B treated with peginterferon alfa-2a at $100 \mu \mathrm{g} / \mathrm{m}^{2}$ once weekly for 48 weeks. Methods: HBV DNA was assessed by qPCR method. Results: After four weeks of treatment six adolescents had undetectable HBV DNA $(<12 \mathrm{IU} / \mathrm{mL})$. Seven adolescents - including five HBV negatives at week 4 - had undetectable HBV DNA $(<55 \mathrm{IU} / \mathrm{mL})$ at week 24, and seven adolescents - including all HBV DNA negatives at week 4 - had undetectable HBV DNA at week 48 of treatment $(<55 \mathrm{IU} / \mathrm{mL})$. Five adolescents had undetectable HBV DNA $(<55 \mathrm{IU} / \mathrm{mL})$ after 24 weeks of followup (sustained viral response). $\mathrm{HBeAg}$ seroconversion was achieved in one patient. HBsAg loss was documented at the end of therapy in two of the six adolescents HBV DNA negative at week 4 of treatment. Three adolescents withdrew from the treatment (two because of adverse events, one because of withdrawal of parental consent). Leukopenia was reported in seven adolescents and three individuals experienced thrombocytopenia. Except for one patient who discontinued treatment due to leukopenia, no dose modifications for adverse events or laboratory abnormalities were required. Conclusion: This pilot study shows that 48 weeks of treatment with peginterferon alfa-2a can result in sustained HBV DNA suppression, $\mathrm{HBeAg}$ seroconversion and $\mathrm{HBsAg}$ loss in adolescents with $\mathrm{CHB}$. Larger and longer trials are now required to better define the magnitude of the benefit in this group of patients.

Key words: chronic hepatitis B, hepatitis B virus, peginterferon alfa2a, thrombocytopenia

Received: 25 February, 2012; revised: 23 November, 2012; accepted: 26 November, 2012; available on-line: 30 November, 2012

\section{INTRODUCTION}

Hepatitis $\mathrm{B}$ virus (HBV) infection continues to be a global health problem. Approximately 400 million people worldwide are chronically infected with the virus of whom 500000 die each year from complications such as cirrhosis and hepatocellular carcinoma (Ghany \& Doo, 2006; Perz et al., 2006). It generally takes decades for chronic hepatitis $\mathrm{B}(\mathrm{CHB})$ to progress to the point at which liver complications manifest; thus, individuals who acquire the virus vertically during childbirth, or at a young age are a priority for effective treatment.

Chronic HBV infection cannot be eradicated. Currently approved therapies include nucleoside and nucleotide analogues that suppress viral replication, and interferon alfa, an immune modulator (Keeffe et al., 2008; EASL 2009). A major advantage of interferon-based therapy for $\mathrm{CHB}$ is that the therapeutic response is sustained in a substantial proportion of patients after a 6-12-month course of treatment. Peginterferon alfa- $2 \mathrm{a}$ is approved for the treatment of hepatitis B e antigen (HBeAg)-positive and $\mathrm{HBeAg-negative} \mathrm{adults} \mathrm{in} \mathrm{whom} \mathrm{it} \mathrm{has} \mathrm{been}$ shown to be effective (Marcellin et al., 2004; Lau et al., 2005). The drug is recommended as a first line treatment option for $\mathrm{CHB}$ in adults (Lok \& McMahon, 2007; Keeffe et al., 2008; Liaw et al., 2008; EASL 2009). However, there are few data on the efficacy and safety of interferon-based therapies, including pegylated interferon, in children. For this reason we conducted a pilot study in adolescents with CHB.

\section{MATERIALS AND METHODS}

Patients. Adolescents eligible for treatment in the trial had CHB as evidenced by the presence of HBsAg and HBV DNA in serum and elevated serum ALT activity during two years prior to the treatment. Both HBeAgpositive and $\mathrm{HBeAg}$-negative patients were enrolled.

All patients had a liver biopsy and liver ultrasonography as a prerequisite to enrolment and treatment. Liver biopsy specimens were scored according to the modified Scheuer scale and were assigned a grade for necroinflammation between 0 and 4 and a stage between 0 and 4 for fibrosis. Patients with histological evidence of hepatocellular carcinoma or chronic liver disease other than CHB were excluded.

Patients co-infected with hepatitis $\mathrm{C}$ virus or human immunodeficiency virus were not eligible for treatment. Patients were excluded if they had previously been treated at any time for $\mathrm{CHB}$ with nucleoside analogues.

Treatment. Eligible patients received peginterferon alfa-2a (40 kDa) (PEGASYS ${ }^{\circledR}$, Roche, Basel, Switzerland) at a dosage of $100 \mu \mathrm{g} / \mathrm{m}^{2}$ once weekly for 48 weeks by subcutaneous injection.

Study conduct. The protocol was approved by the ethics committee of the Nicolaus Copernicus University. Informed consent was provided in writing by a legal guardian of each patient before treatment was initiated.

Treatment outcomes. During treatment patients were required to return to the clinic at regular intervals at which time blood samples were obtained for determination of serum HBV DNA, HBeAg, HBsAg, and ALT activity. A complete blood count was performed at each visit.

e-mail: mpawlowska@cm.umk.pl

Abbreviations: $\mathrm{CHB}$, chronic hepatitis $\mathrm{B}$; $\mathrm{HBV}$, hepatitis $\mathrm{B}$ virus 
Table 1. Baseline characteristics

\begin{tabular}{|c|c|c|c|}
\hline & HBeAg-positive & HBeAg-negative & All patients \\
\hline & $\mathrm{N}=5$ & $\mathrm{~N}=8$ & $\mathrm{~N}=13$ \\
\hline Mean age, years (range) & $14.4 \pm 2.4(12-17)$ & $13.7 \pm 2.1(11-16)$ & $14 \pm 2.2(11-17)$ \\
\hline Male: female & $3: 2$ & $6: 2$ & $9: 4$ \\
\hline Mean body weight, kg & $49.7 \pm 7.6$ & $50.7 \pm 7.3$ & $50.4 \pm 7.1$ \\
\hline Mean serum $A L T$, IU/Lbc & $82 \pm 57$ & $19 \pm 4$ & $43 \pm 46$ \\
\hline Mean fibrosis stage ${ }^{a}$ & $1.4(1-2)$ & $1.12(0-2)$ & 1.23 (range 0-2) \\
\hline Mean necroinflammatory grade ${ }^{a}$ & 1.8 (range 1-2) & 1.25 (range 1-2) & 1.46 (range 1-2) \\
\hline $\begin{array}{l}\text { Median HBV DNA level IU/mL } \times 10^{3} \text { (interquartile } \\
\text { range), }\end{array}$ & $\begin{array}{l}19.6 \\
(7.2-67.4)\end{array}$ & $\begin{array}{l}3.68 \\
(0.127-7.8)\end{array}$ & $\begin{array}{l}7.8 \\
(1.82-19.6)\end{array}$ \\
\hline Previous treatment with Interferon alfa & 3 & 1 & 4 \\
\hline
\end{tabular}

aAccording to the modified Scheuer scale 0-4 for grading and 0-4 for staging; bUpper limit of normal: females 31 IU/L; males 40 IU/L; ${ }^{\circ} \mathrm{All}$ patients had ALT > upper limit of the normal range (ULN) during the 2 years prior to treatment although ALT<ULN may have been recorded at start of treatment

Serum HBV DNA was determined upon initiation of treatment, at week 4, 24 and 48 during treatment and after 24 weeks of untreated follow-up (study week 72) by quantitative polymerase chain reaction (qPCR) assay (COBAS ${ }^{\circledR}$ AmpliPrep/COBAS TaqMan ${ }^{\circledR}$ HBV Test, limit of quantitation $=55 \mathrm{IU} / \mathrm{mL}$; limit of detection 12 $\mathrm{IU} / \mathrm{mL}$ [Roche Diagnostics]).

Rapid virological response (RVR) was defined as undetectable HBV DNA in serum $(<12 \mathrm{IU} / \mathrm{mL})$ at week 4 of treatment. An end of treatment response was defined as undetectable HBV DNA $(<55 \mathrm{IU} / \mathrm{mL})$ in serum at week 48. Sustained virological response (SVR), the primary efficacy outcome in the trial, was defined as undetectable HBV DNA $(<55 \mathrm{IU} / \mathrm{mL})$ in serum 24 weeks after the end of treatment (study week 72 ).

Safety was monitored at each clinic visit by means of laboratory tests, physical examination and adverse events reported by the patient or guardian.

Statistical analysis. Serum HBV DNA levels were analysed by descriptive statistics. Means and standard deviations and median values and interquartile ranges were calculated for values collected at week 4, 24 and 48 during treatment and after 24 weeks of untreated follow-up (study week 72). For the purposes of calculations, undetectable HBV DNA results $(<12 \mathrm{IU} / \mathrm{mL}$ at week 4 and $<55 \mathrm{IU} / \mathrm{mL}$ at weeks 24,48 and 72 ) were set to $0 \mathrm{IU} /$ $\mathrm{mL}$.

\section{RESULTS}

A total of 13 patients (nine boys and four girls), aged 11 to 17 years, and with CHB were enrolled between October and November 2006 and treated with peginterferon alfa-2a at doses ranging from 135 to $180 \mu \mathrm{g} /$ week. Five patients were $\mathrm{HBeAg}$-positive and eight $\mathrm{HBeAg}$ -

Table 2. Median HBV DNA (interquartile range) $x 103 \mathrm{IU} / \mathrm{mL}$

\begin{tabular}{llll}
\hline & $\begin{array}{l}\text { HBeAg-positive } \\
(\mathrm{N}=5)\end{array}$ & $\begin{array}{l}\text { HBeAg-negative } \\
(\mathrm{N}=8)\end{array}$ & $\begin{array}{l}\text { All patients } \\
(\mathrm{N}=13)\end{array}$ \\
\hline Baseline & $19.6(7.2-67.4)$ & $3.68(0.127-7.8)$ & $7.8(1.8-19.6)$ \\
Week 4 & $6.76(3.6-12.6)$ & $0(0-0.0035)$ & $0.0451(0-5.18)$ \\
Week 24 & $4.14(26.5-8.66)$ & $0(0-0)$ & $0(0-26.5)$ \\
Week 48 & $11.3(8.4-61.5)$ & $0(0-0)$ & $0(0-8.4)$ \\
Week 72 & $16.2(1.01-110.0)$ & $0.77(0-1.22)$ & $1.01(0-11.5)$ \\
\hline
\end{tabular}

negative. Four patients had previously been treated with recombinant interferon alfa.

The baseline characteristics of the patients are presented in Table 1. All patients had ALT > upper limit of the normal range (ULN) during the 2 years prior to treatment. No patient had severe liver disease assessed as greater than grade 2 , stage 2 on the pretreatment liver biopsy but had at least grade 1 and/or stage 1 at baseline.

\section{Efficacy}

HBV DNA levels decreased in all patients during treatment with peginterferon alfa-2a. Median HBV DNA levels at baseline, during treatment and at the end of follow-up are presented in Table 2. Individual patient data are shown in Table 3.

After 4 weeks of treatment, the overall median HBV DNA level decreased from $7.8 \times 10^{3} \mathrm{IU} / \mathrm{mL}$ at baseline to $0.045 \times 10^{3} \mathrm{IU} / \mathrm{mL}(p<0.01)$. Six of the 13 adolescents, all of whom were $\mathrm{HBeAg}$-negative at baseline, achieved an RVR (undetectable HBV DNA $<12 \mathrm{IU} / \mathrm{mL}$ at week 4). Patients with an RVR had lower pretreatment ALT levels (mean 20 \pm , range 15-25 IU/L vs $63 \pm 57$ $\mathrm{IU} / \mathrm{L}$, range 13-177 in patients without an RVR). Patients with an RVR also had lower pretreatment viral loads (HBV DNA median $12.8 \mathrm{IU} / \mathrm{mL}$ vs $14400.0 \times 10^{3}$ $\mathrm{IU} / \mathrm{mL}$, in patients without an RVR). All patients with an RVR were HBeAg-negative pretreatment and had ALT levels at baseline within the normal range.

At weeks 4, 24 and 48, a total of five patients had undetectable HBV DNA. At week 48, seven patients had undetectable HBV DNA, including six who had RVR at week 4.

At the end of untreated follow-up (week 72) median HBV DNA levels were lower than the baseline value, overall and in the $\mathrm{HBeAg}$-positive and $\mathrm{HBeAg}$-negative subgroups (Table 2). At week 72, five adolescents achieved an SVR including three with RVR at week 4. For the other three patients with RVR at week 4, they also achieved undetectable HBV DNA at the end of 48 weeks treatment, but HBV DNA rebounded after the treatment ended and its levels at week 72 were similar to the baseline data. Of the two patients who had an SVR without an RVR, one $\mathrm{HBeAg}$-negative patient had HBV DNA levels below the level of quantitation $<55 \mathrm{IU} / \mathrm{mL}$ at weeks 4 and 24 , while the other patient, who was HBeAg-pos- 


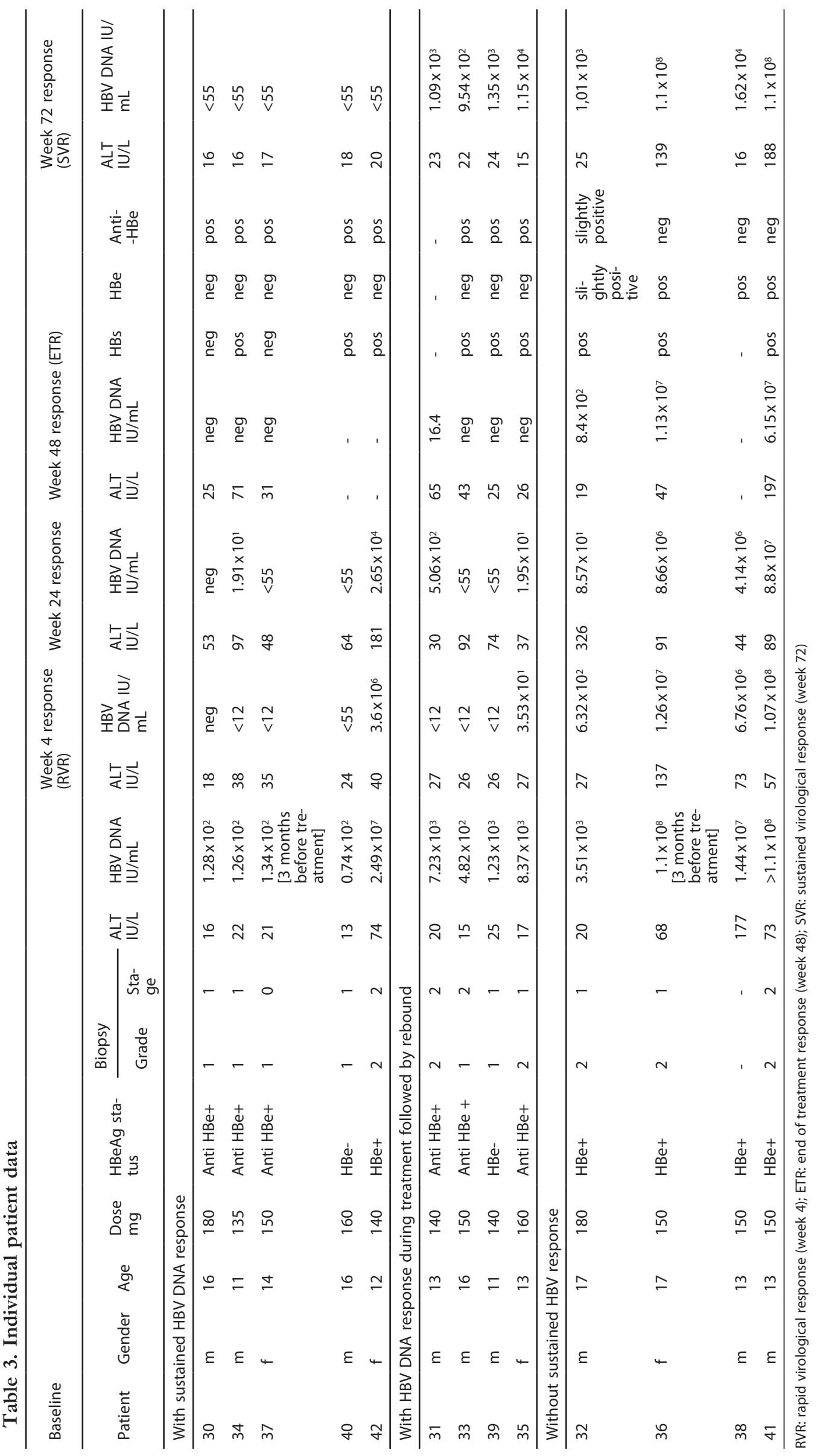


itive, had an HBeAg seroconversion at week 48. This patient had an abnormal ALT $(74 \mathrm{IU} / \mathrm{ml})$ and higher HBV DNA $\left(2.49 \times 10^{7} \mathrm{IU} / \mathrm{ml}\right)$ at baseline. Although the patient did not reach an RVR at week 4, her HBV DNA level continued to decrease throughout the course of treatment; the patient withdrew from the treatment at week 37 due to adverse event. No HBV DNA data was available for week 48, but HBV DNA was undetectable at week 72. No patient exhibited $\mathrm{HBeAg}$ loss without seroconversion.

Loss of HBsAg after the end of treatment was documented in two of the six adolescents who had an RVR at week 4. Both these patients were $\mathrm{HBeAg}$-negative, had normal ALT and lower HBV DNA $\left(1.28 \times 10^{2}\right.$ and $1.34 \times 10^{2} \mathrm{IU} / \mathrm{ml}$, respectively) at baseline and both also achieved ETR and SVR.

\section{Safety}

Three patients discontinued treatment prematurely. One patient was withdrawn after 8 months of treatment because of no viral response and some auto-immunological markers - an increase of serum IgG level, hypergammaglobulinemia and ANA appearance in the serum (no. 38). A second child (no. 42) had a treatment - related adverse event of hypergammaglobulinemia, leukopenia and increased ALT and GGT activity starting at 6 months of treatment (with no other liver function test abnormalities). This patient was withdrawn from treatment at week 37 and the event resolved 6 months after treatment, with ALT, GGT and gammaglobulins returning to normal values. This patient was the one $\mathrm{HBeAg}$ positive patient who had an $\mathrm{HBeAg}$ seroconversion. The third patient (no. 40) had undetectable HBV DNA after 24 weeks of treatment when withdrawn because of the parents' decision.

There were no serious adverse events reported. The only other treatment — related adverse events that occurred were: eye ball pain which was mild, transient and resolved without any clinical consequences, hair loss and headache were mild and resolved, and raised ALT levels to $4.5 \times \mathrm{ULN}$.

Leukopenia defined as $\leq 3 \times 10^{3}$ cells $/ \mu \mathrm{L}$ was reported in seven patients and thrombocytopenia defined as $\leq 100 \times 10^{3}$ cells $/ \mu \mathrm{L}$ in three patients.

Except for one patient who discontinued treatment due to leukopenia, no dose modifications for adverse events or laboratory abnormalities were required.

There was no overall effect of treatment on growth. All but one patient showed an increase in height between baseline and week 72 (mean increase $5.31 \pm 4.19$ $\mathrm{cm}$; range $0-12 \mathrm{~cm}$ ).

\section{DISCUSSION}

The results of this study demonstrate that a 48 -week course of peginterferon alfa-2a therapy in adolescents can produce sustained suppression of HBV DNA replication in $\mathrm{HBeAg}$-positive and $\mathrm{HBeAg-negative} \mathrm{individu-}$ als, and can result in $\mathrm{HBeAg}$ seroconversion in $\mathrm{HBeAg-}$ positive individuals. At the end of treatment more than half of the adolescents enrolled in the trial had undetectable serum HBV DNA and after 24 weeks of untreated follow-up five of 13 individuals still had undetectable HBV DNA levels and thus a post-treatment sustained virological response. These results are clinically significant because HBV DNA levels are correlated with an increased risk of liver disease. There is a linear relationship between the serum concentration of HBV DNA and the long-term risk of cirrhosis and hepatocellular carcinoma in patients with CHB (Marcellin et al., 2004; Lok \& McMahon, 2007; Liaw et al., 2008). Consistent with these observations, suppression of HBV replication with lamivudine reduced morbidity and mortality in patients with $\mathrm{CHB}$ and advanced hepatic fibrosis (Chen et al., 2006). However, to obtain these benefits with a nucleoside analogue such as lamivudine, prolonged therapy is necessary, which is associated with increasing rates of drug resistance, and, as noted above, sustained response rates are significantly lower with lamivudine than with peginterferon alfa-2a (Lau et al., 2005; EASL 2009).

Interestingly, three of the five patients in our series showed an RVR, with HBV DNA suppressed to undetectable levels already after the initial 4 weeks of therapy and two of these patients even cleared the HBsAg during follow up. Given recent observations on the use of $\mathrm{HBsAg}$ quantification during peginterferon alfa-2a therapy to predict sustained response (Moucari et al., 2009; Brunetto et al., 2009), it would be of interest to investigate the potential of $\mathrm{HBsAg}$ level quantification also in our population.

The goal of therapy for $\mathrm{CHB}$ is the achievement of sustained immune control ( $\mathrm{HBeAg}$ seroconversion in $\mathrm{HBeAg}$-positive patients and HBV DNA < 10000 copies $/ \mathrm{mL}$ in HBeAg-negative patients) and remission of liver disease (Lok \& McMahon, 2007; Piratvisuth et al., 2010; Marcellin et al., 2010). Durable suppression of HBV DNA replication results in histological improvement, normalization of ALT levels and, in some patients with $\mathrm{HBeAg}$-positive disease, seroconversion to an anti$\mathrm{HBe}$ state. Clearance of HBsAg has been shown to be associated with interferon-based therapy. For example, in adult patients treated with peginterferon alfa- $2 \mathrm{a}$ the rate of $\mathrm{HBsAg}$ clearance increased during post-treatment follow up to $12 \%$ after 5 years (Marcellin et al., 2009).

Effective treatment is particularly important in children with $\mathrm{CHB}$, because the virus cannot be eradicated and, as a result, complications can evolve over many decades in these individuals. Several studies have suggested that $\mathrm{CHB}$ acquired during childhood is a benign disease (Bortolotti et al., 1990; Fujisawa et al., 2000; Bortolotti et al., 2006; Iorio et al., 2007); however, decompensated liver disease and cirrhosis have been reported in children (Chang et al., 1991; Chang et al., 1997; Ni et al., 2004; Bortolotti et al., 2006). It remains to be confirmed that more rapid $\mathrm{HBeAg}$ seroconversion after therapy with peginterferon alfa- $2 \mathrm{a}$ can prevent the long term complications of CHB in adolescents.

In our study group, treatment with peginterferon alfa2a was well tolerated, with only one patient withdrawing because of adverse events during the study. Although based on only as small number of adolescents, no serious safety issues emerged in this population and the safety profile was not dissimilar to that seen in studies of peginterferon alfa-2a in adults (Marcellin et al., 2004; Lau et al., 2005).

In conclusion, the results of this pilot study show that treatment with peginterferon alfa-2a for 48 weeks results in sustained immune control (sustained suppression of HBV DNA or HBeAg seroconversion) and $\mathrm{HBsAg}$ clearance in a substantial proportion of adolescents with $\mathrm{CHB}$. Larger and longer trials are now required to better define the magnitude of the benefit in this population.

\section{REFERENCES}

Bortolotti F, Cadrobbi P, Crivellaro C, Guido M, Rugge M, Noventa F, Calzia R, Realdi G (1990) Long-term outcome of chronic type B 
hepatitis in patients who acquire hepatitis B virus infection in childhood. Gastroenterology 99: 805-810.

Bortolotti F, Guido M, Bartolacci S, Cadrobbi P, Crivellaro C, Noventa F, Morsica G, Moriondo M, Gatta A Bortolotti F, Guido M (2006) Chronic hepatitis B in children after e antigen seroclearance: final report of a 29-year longitudinal study. Hepatology 43: 556-562.

Brunetto MR, Moriconi F, Bonino F, Lau GK, Farci P, Yurdaydin C, Piratvisuth T, Luo K, Wang Y, Hadziyannis S, Wolf E, McCloud P, Batrla R, Marcellin P (2009) Hepatitis B virus surface antigen levels: a guide to sustained response to peginterferon alfa-2a in HBeAgnegative chronic hepatitis B. Hepatology 49: 1141-1150.

Chang MH, Chen PJ, Chen JY, Lai MY, Hsu HC, Lian DC, Liu YG, Chen DS (1991) Hepatitis B virus integration in hepatitis B virus-related hepatocellular carcinoma in childhood. Hepatology 13: 316-320.

Chang MH, Chen CJ, Lai MS, Hsu HM, Wu TC, Kong MS, Liang DC, Shau WY, Chen DS (1997) Universal hepatitis B vaccination in Taiwan and the incidence of hepatocellular carcinoma in children. Taiwan Childhood Hepatoma Study Group. $N$ Engl J Med 336: 1855-1859.

Chen CJ, Yang HI, Su J, Jen CL, You SL, Lu SN, Huang GT, Iloeje UH (2006) Risk of hepatocellular carcinoma across a biological gradient of serum hepatitis B virus DNA level. JAMA 295: 65-73.

European Association for the Study of the Liver (2009) EASL Clinical practice guidelines: management of chronic hepatitis B. J Hepatol 50: 227-242.

Fujisawa T, Komatsu H, Inui A, Sogo T, Miyagawa Y, Fujitsuka S, Sekine I, Kosugi T, Inui M (2000) Long-term outcome of chronic hepatitis B in adolescents or young adults in follow-up from childhood. I Pediatr Gastroenterol Nutr 30: 201-206.

Ghany MG, Doo EC (2006) Assessment and management of chronic hepatitis B. Infect Dis Clin North Am 20: 63-79.

Iorio R, Giannattasio A, Cirillo F, Vegnente A (2007) Long-term outcome in children with chronic hepatitis B: a 24 -year observation period. Clin Infect Dis 45: 943-949.

Keeffe EB, Dieterich DT, Han SH, Jacobson IM, Martin P, Schiff ER, Tobias H (2008) A treatment algorithm for the management of chronic hepatitis B virus infection in the United States: 2008 update. Clin Gastroenterol Hepatol 6: 1315-41.

Lau GK, Piratvisuth T, Luo KX, Marcellin P, Thongsawat S, Cooksley G, Gane E, Fried MW, Chow WC, Paik SW, Chang WY, Berg T, Flisiak R, McCloud P, Pluck N (2005) Peginterferon Alfa-2a, lamivudine, and the combination for $\mathrm{HBeAg}$-positive chronic hepatitis B. N Engl J Med 352: 2682-2695.
Liaw YF, Leung N, Kao JH, Piratvisuth T, Gane E, Han KH, Guan R, Lau GKK, Locarnini S (2008) Asian-Pacific consensus statement on the management of chronic hepatitis B: a 2008 update. Hepatol Int 2: 263-283.

Lok AS, McMahon BJ (2007) Chronic hepatitis B. Hepatology 45: 507539.

Marcellin P, Lau GK, Bonino F, Farci P, Hadziyannis S, Jin R, Lu ZM, Piratvisuth T, Germanidis G, Yurdaydin C, Diago M, Gurel S, Lai MY, Button P, Pluck N (2004) Peginterferon alfa-2a alone, lamivudine alone, and the two in combination in patients with HBeAg-negative chronic hepatitis B. N Engl J Med 351: 1206-1217.

Marcellin P, Piratvisuth T, Brunetto MR, Bonino F, Lau GK, Farci P, Yurdaydin C, Gurel S, Wu J, Popescu M (2009) Increasing rates of $\mathrm{HBsAg}$ clearance and seroconversion in patients with $\mathrm{HBeAg}$ negative disease treated with peginterferon alafa-2a \pm lamivudine: results of 5 -year post-treatment follow-up. J Hepatol $\mathbf{5 0}$ (Suppl 1): S336 (A924).

Marcellin P, Piratvisuth T, Brunetto M, Bonino F, Farci P, Yurdaydin C, Gurel S, Kapprell HP, Messinger D, Popescu M (2010) Ontreatment decline in serum $\mathrm{HBs} A g$ levels predicts sustained immune control 1 year post-treatment and subsequent HBsAg clearance in HBeAg-negative hepatitis B virus-infected patients treated with peginterferon alfa-2a [40KD] (PEGASYS). Hepatol Int 4: PP209.

Moucari R, Korevaar A, Lada O, Martinot-Peignoux M, Bowyer N, Mackiewicz V, Davergne A, Cardoso AC, Asselah T, Chanoine MHN, Vidaud M, Valla D, Bedossa P, Marcellin P (2009) High rates of $\mathrm{HBsAg}$ seroconversion in $\mathrm{HBeAg}$-positive chronic hepatitis $\mathrm{B}$ patients responding to interferon: a long-term follow-up. J Hepatol 50: 1084-1092.

Ni YH, Chang MH, Wang KJ, Hsu HY, Chen HL, Kao JH, Yeh SH, Jeng YM, Tsai KS, Chen DS (2004) Clinical relevance of hepatitis B virus genotype in children with chronic infection and hepatocellular carcinoma. Gastroenterology 127: 1733-1738.

Perz JF, Armstrong GL, Farrington LA, Hutin YJ, Bell BP (2006) The contributions of hepatitis $\mathrm{B}$ virus and hepatitis $\mathrm{C}$ virus infections to cirrhosis and primary liver cancer worldwide. J Hepatol 45: 529-538.

Piratvisuth T, Lau GKK, Marcellin P, Brunetto MR, Kapprell HP, Popescu M (2010) On-treatment decline in serum HBsAg levels predicts sustained immune control and $\mathrm{HBsAg}$ clearance 6 months post-treatment in $\mathrm{HBeAg}$-positive hepatitis $\mathrm{B}$ virus-infected patients treated with peginterferon alfa-2a [40KD] (PEGASYS). Hepatol Int 4: PP211. 